\title{
On a New Method of investigating Fossil Plant Impressions or Incrustations. ${ }^{1}$
}

\author{
$\mathrm{BY}$ \\ JOHN WALTON, M.A., \\ Junior Demonstrator in Botany, Cambridge.
}

With Plate IX and one Figure in the Text.

\section{INTRODUCTORY.}

T NTIL comparatively recently in descriptions of fossil impressions, or incrustations as they are more correctly called, authors have generally confined themselves to descriptions of the external morphology of the plant as it is exposed on the surface of the rock. The source of information is thus limited to one surface of the plant. Refinements have been used in later years. The 'collodion film method' ${ }^{2}$ suggested by Nathorst has enabled us to investigate with greater facility the finer details of surface markings. Nathorst's method consists in taking a thin transparent cast of the surface features by applying a drop of a solution of collodion in ether to the surface of the fossil. A tough film of collodion is formed on evaporation of the solvent; this can be stripped off and examined by transmitted light. The collodion method is of great assistance, as it is very difficult to examine the surface of a rock under the higher powers of a microscope owing to the necessary use of reflected light. In some instances, however, use may be made of one of the improved forms of vertical illuminator. ${ }^{3}$ A $\frac{1}{6}$-in. objective can be used conveniently with this instrument. The preservation must be good and the surface of the plant must not be pitted by contact with coarse particles in the matrix in which it has been embedded.

I have made use of the vertical illuminator for the examination of

1 Examples of fossil plants prepared by this method were exhibited by the writer in Section $\mathrm{K}$ (Botany), British Association, Hull, $19^{22}$.

2 Nathorst, A. G. (1907). For a description in English see Bather, F. A. (1907).

${ }^{3}$ The writer is indebted to Mr. S. M. Wadham, who suggested that the Leitz-Wetzler vertical illuminator might be used in the examination of fossil plants.

[Annals of Botany, Vol. XXXVII. No. CXLVII. July, 1923.] 
fractured surfaces of blocks of petrified wood. Sometimes the wood has been rendered so transparent and homogeneous in the processes of petrification that no structure can be made out in thin sections of the material. This is not infrequent in silicified wood. In other specimens the wood is quite opaque, when, for example, its structure is preserved in pyrites. In both these types of fossil, examination of a radial fracture will often afford valuable data concerning the structure of the secondary wood: such features as the medullary rays and the pitting on the tracheides show up clearly.

In a specimen of Rhexoxylon africanum, Bancroft, a fossil wood from South Africa of Triassic Age, the pores on the bordered pits showed up very definitely. Similar perfection of detail was observed in a portion of a jasper tree (Triassic) from Arizona in America. In both these specimens the preservation is such that practically no structure is visible in thin sections on examination with transmitted light. A piece of pyritized wood from the Lower Estuarine beds of the Jurassic of the Yorkshire coast showed the features of the pitting very distinctly.

In a few exceptional cases the fossil plant incrustation may become detached from the rock and then both surfaces can be examined. Hamshaw Thomas ${ }^{1}$ described specimens of Thinnfeldia fronds from the Middle Estuarine of Yorkshire that can be stripped with ease from the rock. Sometimes such fossils are transparent and then more information is available. Miss Wills ${ }^{2}$ describes cuticles of Carboniferous plants found in clayey shales in the Upper and Middle Coal Measures which could be removed from the shale by soaking. The fact that coherent samples of the specimens can be obtained is largely due to the excellent state of preservation of the cuticles of the upper and lower surfaces of the leaves. A. G. Nathorst ${ }^{3}$ described Tertiary coniferous twigs from Ellesmere Land, with the leaves attached, which could be similarly removed from the rock.

There are also, of course, intermediate examples in which, by exercising considerable care, small fragments of plants may be detached; but opportunities such as these are rare, and it is not often that we are able to examine specimens which, as Hamshaw Thomas says, ${ }^{4}$ may be regarded as true examples from the 'Herbarium Diluvianum'.

With the realization that a considerable amount of the original plant substance was still preserved in fossil plants, and that the cuticle still exists in an almost unchanged condition, a great advance in the study of these plant impressions was made possible. Schulze ${ }^{5}$ in 1855 introduced a method of isolating portions of the cuticles of such fossils by chemical treatment, and Nathorst employed the same method in many of his researches. In this country Hamshaw Thomas and several other palaeo-

\footnotetext{
1 Thomas, H. Hamshaw (1913).

$s$ Nathorst, A. G. (1915).

5 Schulze, F. (1855).
}

$\begin{array}{ll}{ }^{2} & \text { Wills, Lucy (1914). } \\ { }^{4} & \text { Thomas, H. Hamshaw (1915). }\end{array}$ 
botanists have used this method extensively. So far Schulze's method has been used almost exclusively in the study of Mesozoic plants ; Huth, ${ }^{1}$ however, has shown that it can be employed in the investigation of Carboniferous incrustations.

Now most fossil plants of this encrusted type occur in rocks which have been formed by deposition of sediment in some lake or estuary and have a layered structure, or, in other words, exhibit planes of bedding. The rock splits or cleaves more readily in a direction parallel to these planes than in any other direction.

As the plant fragment is drifted and sinks to the bottom it will generally, if it is a leaf, tend to lie in the plane of the bedding, and that is what is usually found. Occasionally, however, it may settle down and be fixed in a position oblique to the plane of bedding. The presence of a leaf or frond often determines the plane along which the rock cleaves; there seems to be a surface of weakness due to the discontinuity at the surface of the fossil. Very often when a leaf occurs embedded at an angle with the plane of the bedding the rock cleaves along the surface of the fossil and not along the bedding plane of the rock. The split will occur over either the upper or lower surface of the plant, whichever offers least resistance to cleavage; but, other conditions being equal, it will occur over the most even of the two surfaces.

On the whole the upper surface of a leaf, in the mature state usually convex, is the most uniform. The under surface may have prominent veins, hairs, or scales, and the majority of the stomata. On this supposition, therefore, we should expect to find that in the majority of specimens the upper surface of the leaf is exposed on cleavage of the rock in which it is embedded. On the whole this seems to be borne out after examination of a large number of such fossils. If the plane of cleavage did by any chance pass over the lower surface of a leaf which had hairs, scales, or other appendages, these would probably be shorn off and remain embedded in the other half of the block, and would not be represented on the surface of the specimen except by very minute scars, or possibly depressions, so that some of the lower surface features would escape notice even though the lower surface was exposed.

By a method of transferring the fossil on to a transparent base I have been able to examine both surfaces.

There is a very common fern-like frond occurring in Carboniferous strata, Dactylotheca plumosa, Artis sp., the specific name having been given to it presumably on account of the feathery appearance of the multipinnate frond. In the commonest type of specimen of this plant the surfaces of the pinnae and pinnules are convex and smooth. On examining the under surface by the transfer method I found that it was covered with long hairs

1 Huth, W. (1913).

C C 
consisting of branching filaments (P1. IX, Fig. I). The hairs arose principally from the surface of the veins. To check this observation, specimens from different localities were examined and the same features were again apparent. I found one specimen in which the surface of the fossil was concave and had not the smooth appearance so characteristic of the majority. On examination of the unexposed surface by the transfer method $\mathrm{I}$ found it to be smooth and free from emergences. The dull appearance of the specimen was due no doubt to the fact that the hairs detached by the splitting of the block left irregularities on the surface, which was in this example the under surface of the frond.

\section{METHOD OF TRANSFER. ${ }^{1}$}

I. A block or chip bearing a representative portion of the fossil is taken from the specimen by chipping or cutting and roughly trimmed. If the surface of the sample on which the fossil occurs is very uneven it should be levelled as much as possible by scraping or cutting without injuring the plant.

2. A glass slide of suitable size is chosen, and sufficient balsam of the consistency of treacle is put on at one end of the slide. The slide is then placed on a metal plate heated by a Bunsen burner, and the balsam is slowly 'cooked' without being allowed to boil, to remove volatile constituents, until a sample drawn out between the points of a pair of forceps is brittle when cool. The balsam is better overcooked than undercooked.

3. The sample is then placed face downwards on the hot plate for a moment, so that the surface showing the fossil may be heated. It is then placed face downwards on the cooked balsam at one end of the slide, and the slide removed to a cooler portion of the plate. It may be found that bubbles of air have formed between the fossil and the slide, and it will require manipulation to get rid of them.

4. The preparation is cooled in air; rapid cooling in water causes the balsam to crack. The balsam should set hard and brittle.

5. The rough excess of rock is then ground off from the back of the sample on a glass plate with some abrasive such as carborundum, care being taken not to grind too near the fossil.

6. The slide is dried, the exposed surface of the rock moistened with water, and the whole slide dipped into melted paraffin wax. It is then cooled in water and a second and third coat put on in the same way. By cutting round the edge of the rock with a knife the wax can be removed completely from the back of the rock, as it does not stick to the wet surface.

7. The slide, with all the glass portion thus covered with wax, is then

1 In certain details this method resembles that used by Wiman in the investigation of Graptoites. See Wiman (1895). 
put into an etching bath of hydrofluoric acid ( $\mathrm{HF}$ ) and the rock etched away. If there is any effervescence on immersion in the $\mathrm{HF}$ the preparation should be removed at once, as effervescence indicates the presence of a carbonate, probably of calcium, in the rock. If the reaction were allowed to proceed insoluble calcium fluoride $\left(\mathrm{CaF}_{2}\right)$ would be produced. If calcium carbonate $\left(\mathrm{CaCO}_{3}\right)$ is present dilute hydrochloric acid $(\mathrm{HCl})$ must be used as a mordant until all the $\mathrm{CaCO}_{3}$ is removed. The preparation must then be washed thoroughly to remove all traces of soluble calcium salts, and if any matrix insoluble in $\mathrm{HCl}$ is left it will probably be silica or silicates, which may then be removed by treatment in the HF bath.

The etching is continued until the matrix is dissolved or is loosened sufficiently to be washed away by a gentle stream of water. The preparation should not be left too long in the $\mathrm{HF}$ as the balsam is acted on very slightly.

It is often instructive to watch the process of etching by taking the slide out of the bath from time to time, washing, and then examining under the microscope, as portions of other plants embedded in the rock may be seen which are removed in the course of the etching.

8. The preparation is washed in water.

9. The wax is cut away and any excess of balsam on the slide trimmed off if necessary:

I0. It is sometimes advisable to warm up the preparation on the top of a steam oven until the balsam is soft; this ensures that the plant is firmly fixed. Before it is warmed every trace of wax must be scraped away or it may flow over the surface of the balsam and spoil the preparation.

II. The resulting preparation may be covered with hot fused balsam transferred to it on a cover-slip, but there is danger of the plant moving and cracking up if this is attempted. It is generally sufficient to keep the preparation free from dust, and for examination under the microscope glycerine in water can be put on the surface, or some other liquid with a refractive index as near as possible to that of balsam, but which will not dissolve or react chemically with it.

\section{Examples.}

In order to demonstrate the possibilities of this method of preparation in the elucidation of fossil plant structure I give a series of examples of different types of preservation of carbonized impressions from horizons ranging from the Devonian to the Cretaceous. In conjunction with Schulze's method of isolating cuticles the investigation of Coal Measure plants is rendered easier; for after the plant has been transferred the balsam may be dissolved away subsequently and large coherent portions obtained for cuticle preparations. The more uncertain procedure of chipping off small pieces is thus avoided. 


\section{Psilophyton princeps. Dawson.}

Locality: Callendar, Perthshire. Horizon: Lower Old Red Sandstone.

The transfer preparation of a specimen of Psilophyton princeps figured in P1. IX, Fig. I2, at once reveals the presence of a considerable amount of the original organic substance of the plant. It will be seen on examining the figure that the stem is studded with small spine-like emergences which are somewhat irregularly placed over the surface of the plant exposed by this method of preparation. It is possible that some have been knocked off, and that they are therefore not completely represented. It is hoped that further preparations may give more reliable information as to their arrangement on the stem. The general form of the emergences can be made out at the top of Fig. I2. They are somewhat expanded at the base and are flattened in a radial plane (with reference to the axis of the plant). On examination by transmitted light they were found to be transparent and brown in colour and probably represent the cuticularized portions of the original emergences.

It is worth noticing that these spinous structures seem to be better preserved than the rest of the plant represented in the fossil. This is probably due to the greater proportion of cuticularized material in them, and seems to me to suggest that they were probably not structures representing an extension of the area of photosynthetic tissue, and that if they had any function at all it was of a mechanical nature. We know from the researches of Kidston and Lang ${ }^{1}$ that the Rhynie plants which are included in the same group (Psilophytales) as Psilophyton had well-developed cuticles on the stems.

\section{Mariopteris, cf. muricata, Schloth., sp. ${ }^{2}$}

Horizon: Carboniferous.

I am indebted to Mr. Hamshaw Thomas for calling my attention to the work of Huth ${ }^{2}$ on the foliar epidermis of Mariopteris muricata, in which air pores ('Atemporen') comparable in structure to those of Marchantia are described. Mr. Thomas suggested that a structure which occurred on the epidermis of a specimen of Sphenopteris nimmularia (to be described later) resembled the air-pores described by Huth very closely. Huth mentions that Haberlandt, objecting to his theory of the nature of the Atemporen, suggested that they might be hair-bases. As stomata of quite usual type were found on Sphenopteris nummularia, the suggestion that these 'Atemporen' might really be the points of insertion of hairs or emergences of the epidermis seemed possible. More recently Gothan ${ }^{4}$

1 Kidston and Lang (1917), p. 769 .

3 Huth, W. (1913), Fig. 3, p. 16.
2 Dr. Kidston very kindly identified this specimen.

4 Gothan, W. (1915). 
investigated the cuticle of the rachis of Mariopteris muricata, and discovered structures which he concluded were the bases of epidermal emergences.

Some time later I obtained material of Mariopteris, cf. muricata, Schloth., and made some transfer preparations. The under surface was found to be regularly studded with capitate glandular hairs ${ }^{1}$ (Pl. IX, Fig. 2, $h$, and Fig. 5). These glands occurred also on the veins and revolute margins of the pinnules. Portions of the pinnules which became loosened in the etching process were used to make cuticle preparations by Schulze's method. ${ }^{2}$ I found that the cuticles of the upper and under surfaces were easily separable. The upper cuticle (P1. IX, Fig. 3) was apparently identical with that figured by Huth, ${ }^{3}$ and showed structures (Pl. IX, Fig. 3, h., $h^{\prime}$ ') which corresponded exactly to the 'Atemporen ' in form and number. The lower cuticle (Pl. IX, Fig. 4) was of quite a different nature: it was much thinner than the upper, and showed the outlines of the epidermal cells only very faintly. Glandular hairs were frequent, and occasionally I found the cuticularized portions of the supporting cells of a hair, which corresponded so closely with the structures seen on the upper cuticle as to leave no doubt of their similar nature. There was one very interesting fact observed which throws light on the nature of these glands. In many instances numbers of microspores of various types were found attached to the stalks of the glands and to the epidermal cells surrounding them. These spores were not loosened even by prolonged treatment in Schulze's macerating fluid. They were also found scattered in large numbers over the surfaces of the prepared cuticles (Pl. IX, Figs. 3, 3a, and 5). There were few spores in the matrix surrounding the plant, as, could be verified by examination of the transfer preparations, for any spores lying in the bedding plane of the frond would have remained fixed to the balsam. We may therefore conclude with considerable confidence that the spores were sticking to the plant when it fell into the lake or river in the bed of which it was subsequently silted up, and that the glands secreted some sticky substance during the life of the plant.

In addition to these glandular structures, groups of two to six small papillae occurred at frequent regular intervals over the surface of the cuticle of the abaxial surface in areas which corresponded to the spaces between the veins (Pl. IX, Fig. 3). The papillae in these groups surrounded a small area which in some examples was occupied by a small stoma of quite the usual type, consisting of two curved guard cells surrounding a narrow elliptical pore (Pl. IX, Fig. 6). The whole structure was very much smaller than the hair-bases. The papillae may almost certainly be

${ }^{1}$ Cf. glands of Lagenostoma lomaxi. Oliver and Scott (1904), Pl. VI, Figs. 20, 2I, and Pl. VIII, Figs. 17,18 .

2 Schulze, F. (1855).

${ }^{3}$ Huth, W. (1913). 
considered as projections from subsidiary cells surrounding the stoma, which was slightly sunk below the surface. There were at least seventy-five stomata per sq. mm. As an argument against considering the 'Atemporen' as hair-bases, as Haberlandt suggested, Huth writes: 'Ich habe eine recht grosse Anzahl von Mariopteris muricata-Resten in der Hand gehabt, und habe nie, weder mit blossem Auge, noch mit der Lupe, noch mit dem Binokularmikroskop jemals Härchen entdeckt.' This example serves to stress the fact that the exposed surface of a fossil plant has almost always been stripped, by the splitting of the rock, of any emergences it may have borne.

III. Cladotheca undans, (Halle) Lind. and Hutt.sp. Jurassic Estuarine Beds, Gristhorpe Bay, Yorkshire.

As an example of the way in which this method can be employed in the investigation of fertile fronds, I give the results obtained by examination of a specimen of the above fern. Halle ${ }^{1}$ gives a schematic figure of the disposition of the sporangia on the specimens he investigated. As both his specimens had been exposed by splitting open the shale in which they had been embedded, an inaccurate idea of the character of the sorus is given. The sporangia are described as forming two rows, one on each side of a linear placenta, which was probably superimposed over a lateral vein of the pinnule. This apparent arrangement is due to the fact that only the sporangia which lay next to the surface of the lamina are visible (Textfig., 3 and $3 a$ ). Halle' says: 'In places where the coal' (presumably the material of the lamina) 'has been removed, both specimens show fairly clearly the arrangement and structure of the sporangia.'

The split in the shale has occurred over the upper surface of the leaf (Text-fig., 2), and where the material of the lamina has disappeared (Textfig., 3 and $3 a$ ) the sporangia, which were actually in contact with its under surface, can be seen (Halle, ${ }^{2}$ Pl. II, Fig. 2 ), but those sporangia which arose from the placenta at right angles to the under surface of the leaf are embedded out of view in the matrix.

When a transfer preparation (Pl. IX, Fig. 7) was made from a specimen collected in I922 at Gristhorpe, the sori were found to be superposed on the lateral veins of the pinnule (Text-fig., 4), extending from close to the main vein of the pinnule to near the lobed margin of the latter. The sporangia formed a dense covering (Text-fig., $4 a$ ), and only in places where they had presumably fallen off was it possible to see the underlying sorus or vein. It has been already mentioned that fossil plants when detached from the rock may be partially transparent. This type of fossilization is quite common, although in the majority of examples the plants are too fragile to be detached wholesale by mechanical means, such as were

1 Halle, T. G. (1911), p. 6, Fig. I.

${ }^{2}$ Ibid. (1913), loc. cit. Cf. Pl. IX, Fig. 2. 
employed with the above-mentioned leaves of Eretmophyllum and Thinnfeldia. This type of preservation may generally be detected by examination of the fossil on the rock. Such a fossil shows, particularly when wet, a characteristic brownish coloration due to reflection from the surface of the rock through the semi-transparent plant substance. It is possible that this type of fossil was produced by the decay and dissolution of the mesophyll
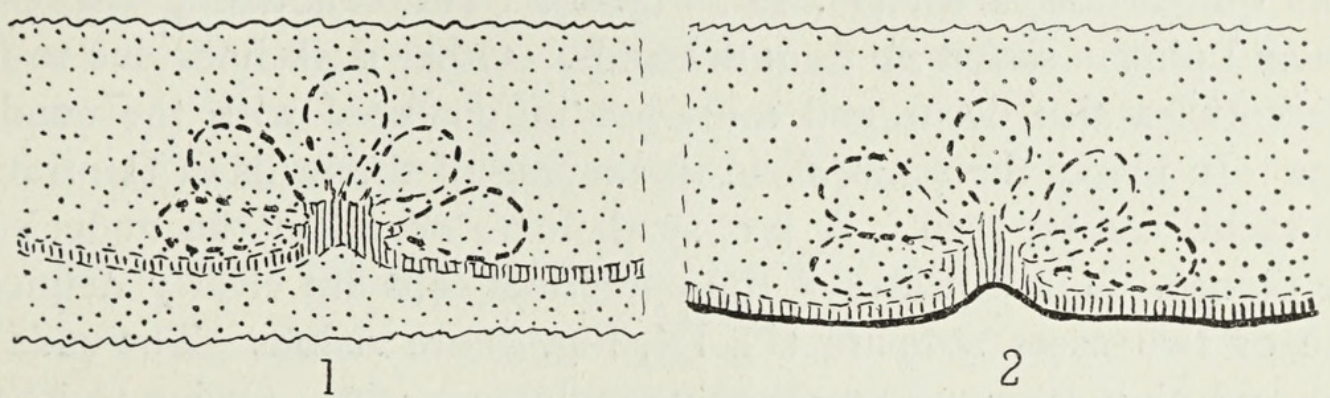

2
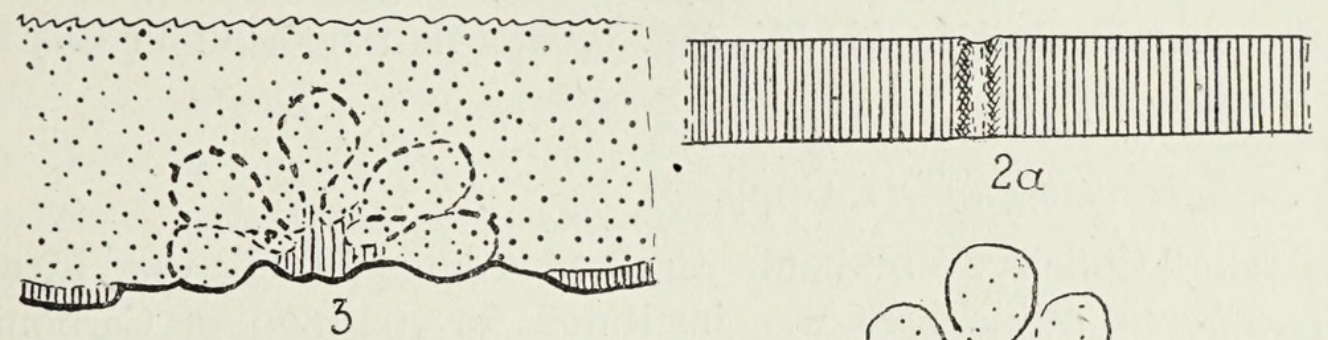

$2 a$

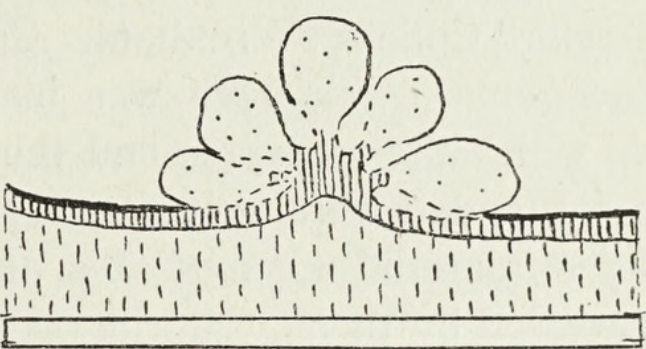

$3 a$

4

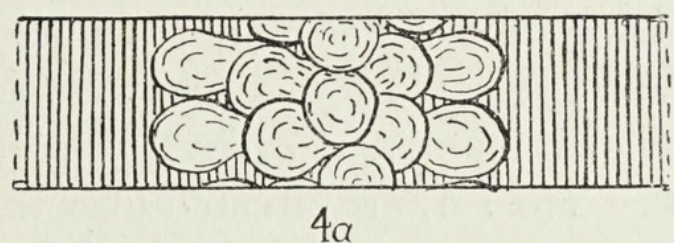

TExt-Fig. Cladotheca undans (Halle): I, transverse section of sorus embedded in the rock; 2 , ditto, upper surface of lamina exposed; $2 a$, surface view of $2 ; 3$, transverse section of sorus with portion of lamina removed, exposing some of the underlying sporangia; $3 \alpha$, surface view of 3 , showing a row of sporangia on each side of the vein; 4 , transverse section of sorus in a transfer preparation; $4 a$, surface view of 4 , showing the sporangia covering the underlying vein. The matrix is represented by dots and the coaly material of the fossil by vertical lines. In 4 the balsam is represented by short vertical strokes.

or softer tissues prior to the plant becoming buried in sediment under conditions in which further dissolution was inhibited. In the larger number of fossil leaves the mesophyll is represented by a black coaly substance which has to be removed before any structure can be seen in the cuticles between which it lies. In Schulze's method ${ }^{1}$ of isolating cuticles the black matter is removed in solution by certain reagents.

1 Schulze, loc. cit. 
The following examples are given of plants which yielded transparent transfer preparations:

IV. Sphenopteris nummularia, Andr.

This specimen has exceptionally tough, well-preserved cuticular surfaces. The mesophyll has decayed, and no black substances are left. The lamina is thus quite transparent (Pl. IX, Fig. 8). The conducting tissue of the rachis and pinnae shows up as dark bands. Other dark lines due to folding of the cuticles also occur, and must not be confused with the conducting system. In places the scalariform thickening of the walls of the tracheides in the rachis can be seen. A few small hairs occur on the under surfaces of the pinnae. The outlines of the epidermal cells are clearly defined, and in one or two cases stomata (Pl. IX, Fig. 9) are visible. The ends of the pinnae and pinnules have a markedly revolute margin. Owing to its toughness, the plant figured in Pl. IX, Fig. 8, was flattened out in soft balsam under a cover-slip.

\section{Oligocarpia gutbieri, Göpp.}

Gresford Colliery, Wrexham. Carboniferous. (Middle Coal Measures.)

The genus Oligocarpia was instituted for a group of Carboniferous ferns, of which the sporangia and the soral arrangement were more or less known. I made several transfer preparations of this plant, as a considerable quantity of material was available, and many interesting details of structure were revealed by them. Sterile and fertile pinnules were observed (Pl. IX, Fig. 10). The lamina in each case was transparent and the venation showed up clearly. The rachis was furnished with scattered hairs, consisting of a filament of cells tapering off to a fine point. In one portion of the surface stomata of the common type could be seen, but it was impossible to tell on which surface the individual stomata occurred. The cuticles of the lamina are not well preserved. The sori are situated over the lateral veins on the fertile pinnules and have two to even sporangia. Some of these sporangia (Pl. IX, Fig. II) are semi-transparent. The annulus appears to be uniseriate in most of those examined, but it is possible that it might be double in a few examples. The sporangia appear to be almost sessile; the stalks must be very short.

\section{Fungus. Cf. Dematiaceae. Carboniferous.}

In several of the transfer preparations made in the course of these investigations, fungal hyphae are found in association with the remains of the vascular plants. Sometimes the hyphae are found on the surfaces of the plants, at others they are found traversing the matrix between them, suggesting that the fungi are found in their place of growth.

In a few preparations spore-forms have been observed. In one pre- 
paration of Gleichenia sp. from the Cretaceous of Greenland spores closely resembling the modern genus Helminthosporium were found in association with the frond. In another preparation a spore-form was found, which is figured in Pl. IX, Fig. I3. It is seen to consist of a mass of septate spores resembling forms found in the recent fungi included in the Dematiaceae, such as Septosporium, Cladosporium, \&c. Although there is in these examples no very conclusive evidence, the nature of the spores strongly suggests that they were developed in subaerial conditions. If this is so, then we must suppose that the plants were rotting on the ground, and were

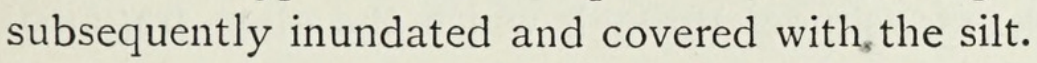

\section{Some General Conclusions.}

I. It is contended that the study of the usual type of fossil plant impression or incrustation gives insufficient data for an accurate description of the plant, and that it is necessary to study the other surface of the plant as well. A method is described by which this may be effected.

2. That in view of the uncertainty which exists at the present day as to the relations between form and function in plants, it is better to avoid trying to reach a definite conclusion as to the ecological conditions under "which Carboniferous plants lived by the examination of a few types only, and that the study of the Coal Measures stratigraphically ${ }^{1}$ gives us at present more reliable information as to the nature of the habitat than observations based on separate types of plants found in them.

\section{SUMMARY.}

I. A method of examining the 'other side' of fossil plant impressions or incrustations is described. Dactylotheca plumosa is quoted as an example of a plant in which the characters of the under surface have escaped notice owing to the fact that, when the matrix is split open and a fossil plant exposed, all hairs or other easily detached projections are removed, and an inaccurate representation of the plant is given.

2. Suggestions are given of the kind of problem which the method may assist to solve. Examples are quoted:

I. Psilophyton princeps. A description is given of the spine-like emergences on the axis.

II. Mariopteris, cf. muricata. Epidermal structures (glands, \&c.) are described and figured. The form of the stomata is shown to be of the usual type, and the structures previously described as air-pores of the Marchantia type are shown to be glandular hair-bases. Figures are given.

III. Cladotheca undans. The arrangement of the sporangia in the sorus is described.

1 Kendal, P. F. (1922). 
IV. Sphenopteris nummularia. A portion of a frond is described in which nothing but the transparent cuticle and traces of the lignified tracheides in the vascular strands are preserved. Stomata of the usual type are described.

V. Oliocarpia gutbieri. Preparations showing sterile and fertile pinnae are figured, also sporangia exhibiting an apparently uniseriate annulus. Stomata of the usual type are recorded.

VI. A fungus (spore-form) is figured. It is suggested that, by a careful study of the position of the hyphae of such fungi, it may be possible to deduce something about the vicissitudes through which the plant fragment has passed before fossilization.

In conclusion, I have to thank Prof. Seward for a great deal of helpful criticism given in the course of this work, and Mr. H. Hamshaw Thomas for invaluable advice in matters of technique and for many of the specimens, some of which he kindly identified.

I am indebted to several members of the staff of the Sedgewick Museum, Cambridge, for the loan of specimens and for references to literature.

\section{BIBLIOGRAPHY.}

Bather, F. A. (1907) : Nathorst's Use of the Collodion Imprints in the Study of Fossil Plants. Geol. Mag., Decade V, vol. iv, No. 520, October.

Gothan, W. (1915): Über die Methoden und neuen Erfolge bei der Untersuchung kohlig erhaltener Pflanzenreste. Sitzungsb. d. Ges. Naturforsch. Freunde, Berlin, Jahrg. I9I5, No, 2.

Halle, T. G. (1911): On the Fructifications of Jurassic Fern-Leaves of the Cladophlebis denticulata Type. Arkiv för Botanik, Band x, No. I5.

Huth, W. (1913): Zur Kenntnis der Epidermis von Mariopteris muricata. Zeitschrift d. Deut. Geol. Gesellschaft, Band lxv, No. 3 .

Kendal, P. F. (1922): The Physiography of the Coal Swamps. President's Address, Section C, British Association, Hull.

Kidston, R., and Lang (1917): Old Red Sandstone Plants showing Structure, \&c. Trans. Roy. Soc., Edin., vol. li, pt. iii, No. 24, I9I7.

Nathorst, A. G. (1902): Tertiäre Pflanzenreste aus Ellesmereland. Report of the Second Norwegian Arctic Expedition in the Fram, 1898-1902, No. 35.

(1907) : Kollodiumaftryck såsom hjälpmedel vid undersökning af fossila växter. Geol. Fören. Förhandl., Bd. xxix.

Oliver, F. W., and Scott, D. H. (1904): On the Structure of the Palaeozoic Seed Lagenostoma Lomaxi. Phil. Trans. Roy. Soc., London, Ser. B, vol. cxevii.

Schulze, F. (1855): Über das Vorkommen wohl erhaltener Zellulose in Braunkohle und Steinkohle. Bericht über die zur Bekanntmachung geeigneten Verhandlungen der Königl. Preuss. Akad. d. Wiss. z. Berlin, p. 676.

Thomas, H. Hamshaw (1915): The Thinnfeldia Leaf Bed of Roseberry Topping. The Naturalist.

(1913): On some New and Rare Jurassic Flants from Yorkshire: Eretmophyllum, a New Type of Ginkgoalian Leaf. Proc. Cambridge Phil. Soc., vol, xvii, pt. iii. 

Annals of Botany,

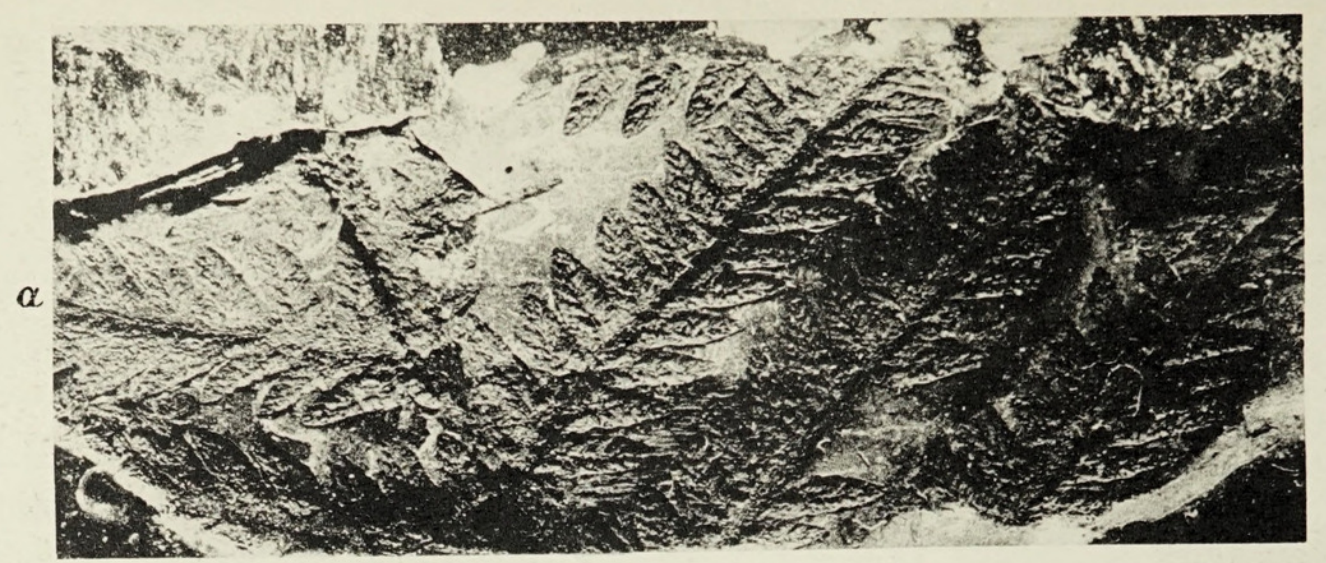

1.
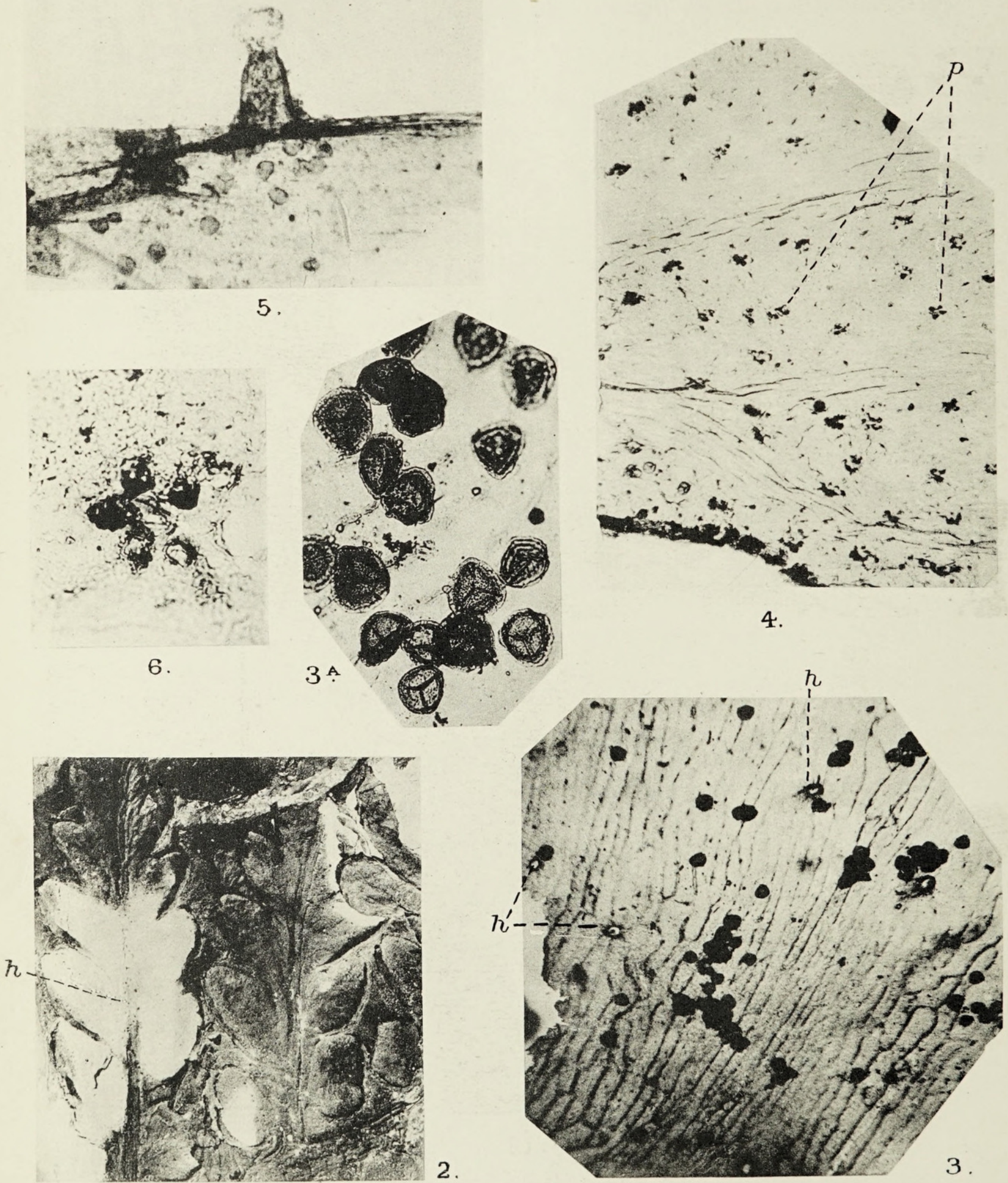

4.

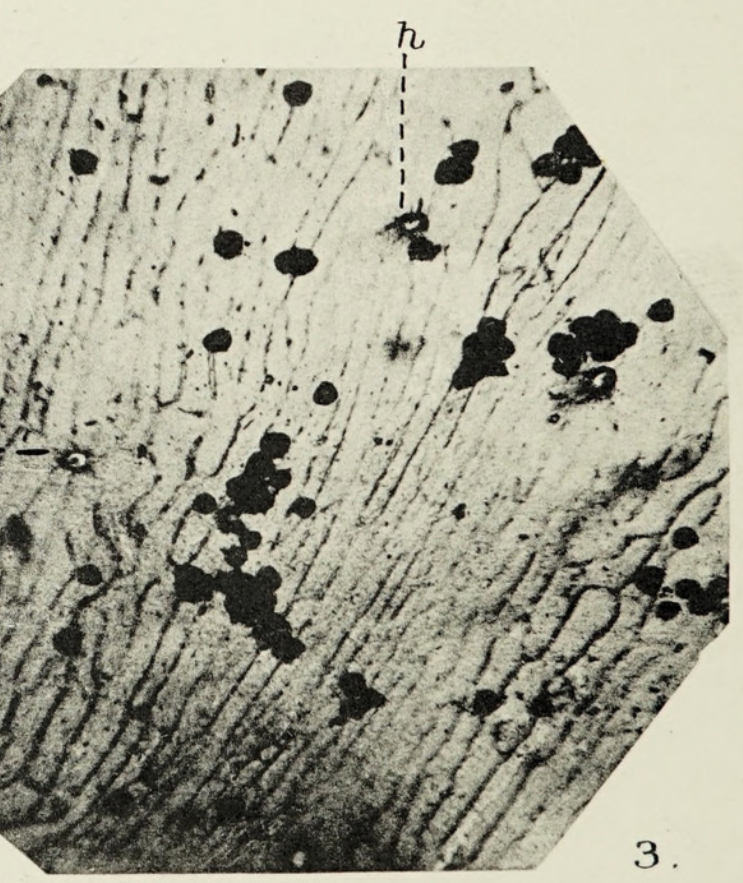



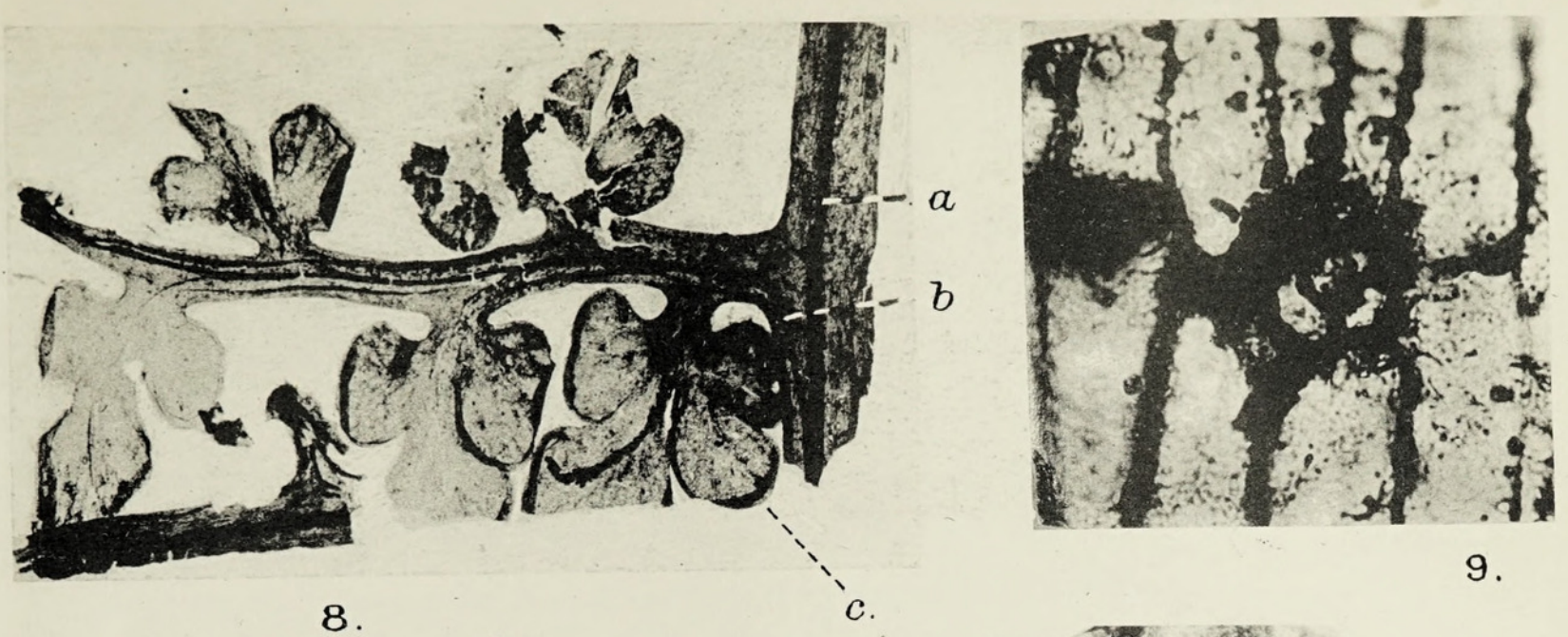

9.
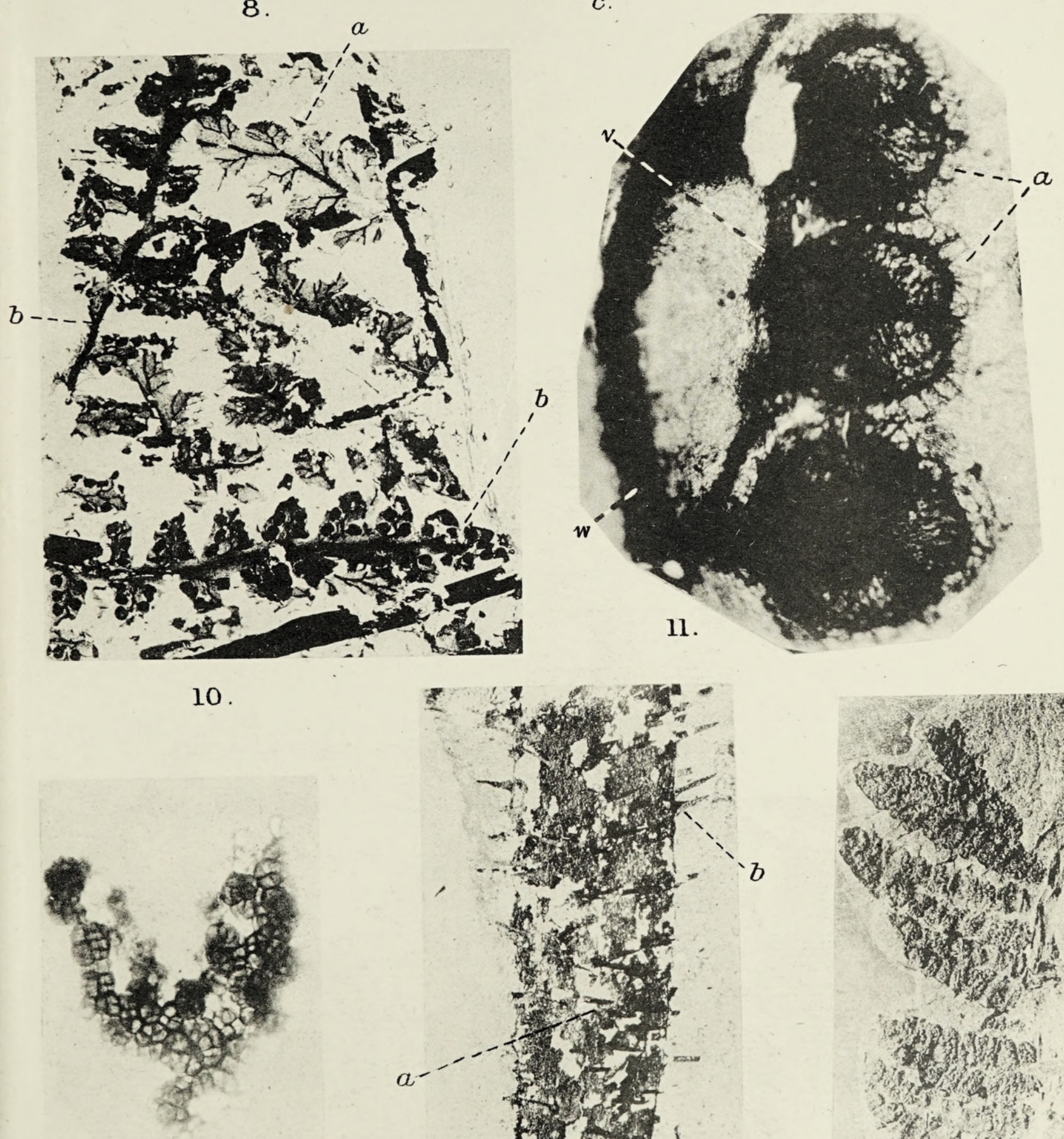

13.

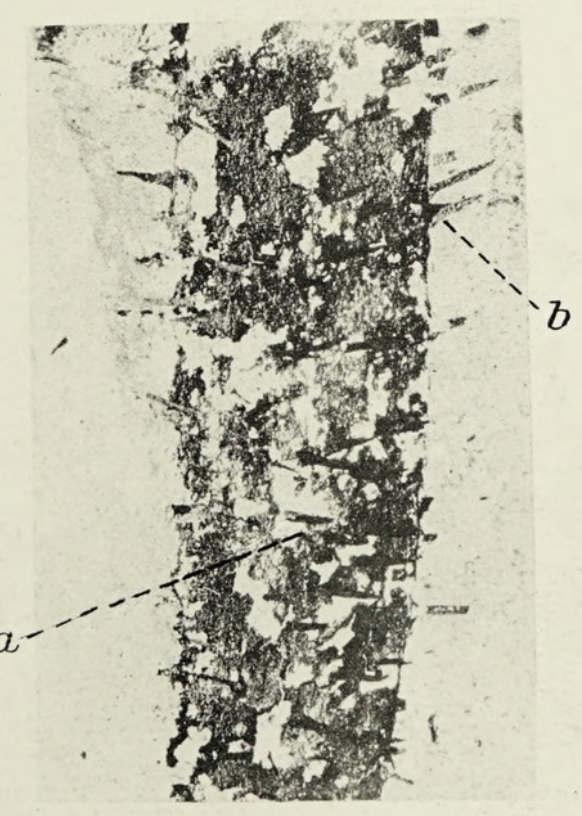

12.

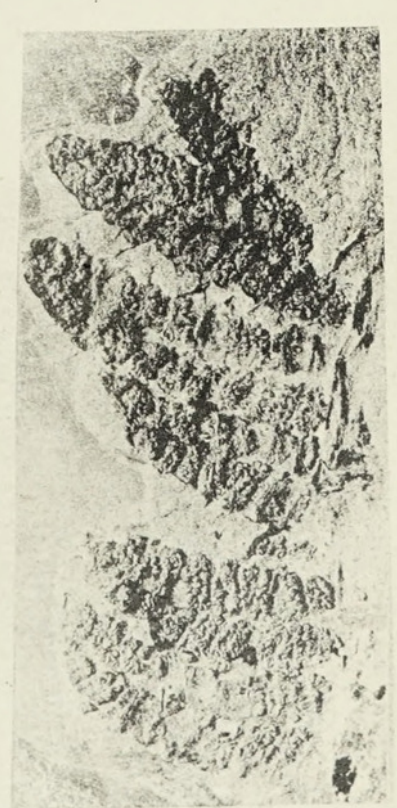

7. 

Wills, Lucy (1914): Plant Cuticles from the Coal Measures of Britain. Geol. Mag., N.S.,

Decade VI, vol. i, September.

Wiman, C. (1895) : (i) Über die Graptoliten. Inaugural-Dissertation, Upsala.

(ii) Sonder-Abdruck aus Bull. of the Geol. Inst. of Upsala, No. 4, vol. ii, pt. ii.

\section{Explanation of Figures in Plate IX.}

Illustrating Mr. Walton's paper on Fossil Plant Impressions or Incrustations.

\section{Dactylotheca plumosa, Artis sp.}

Fig. I. Photograph by reflected light of a transfer preparation, showing the hairy under surface of the frond. The hairs can be seen most clearly at $a . \quad \times 3 \cdot 1$.

\section{Mariopteris, cf. muricata, Schloth.}

Fig. 2. Photograph by reflected light of a transfer preparation. The shale (white in the photograph) has not been etched away completely in order that the glandular hairs, $h$, may be shown projecting through it. $\times 2$.

3. Photograph of upper cuticle. The outlines of the epidermal cells can be seen. Glandular hair-bases at $h$ and $h^{\prime}$. Microspores can be seen sticking to the surface. $\times 60$.

Fig. 3 a. Photograph of upper cuticle with adherent microspores. $\times 230$.

Fig. 4. Photograph of lower cuticle. $v$, small folds in the cuticle marking the courses of the veins; $p$, groups of papillae on the epidermal cells surrounding each stoma. $\times 60$.

Fig. 5. Photograph of a glandular hair situated at the edge of a fold in the cuticle. It is thus seen in profile. Note the microspores sticking to the cuticle near the hair. $\times 8_{3}$.

Fig. 6. Photograph of one of the stomata on the under surface. Note the papillae, in this example five in number, which surround the stomatal depression in the epidermis. The guard-cells of the stoma itself are at a slightly lower level and can be seen within the ring formed by the papillae. $\times 440$.

\section{Cladotheca undans, (Halle) Lind. and Hutt. sp.}

Fig. 7. Photograph by reflected light of a transfer preparation showing the fertile lower surface of a portion of a frond. The linear sori with densely packed sporangia can be distinguished. $\quad \times 2 \cdot 4$.

\section{Sphenopteris nummularia, Andr.}

Fig. 8. Photograph by transmitted light of a transfer preparation of a portion of a frond. $a$, the vascular strand of the rachis; $b$, the vascular strand passing out to the lateral ; $c$, incurved margin of pinnule. $\times 3 \cdot 3$. $\times 400$.

Fig. 9. Photomicrograph of a stoma with the outlines of the surrounding epidermal cells.

\section{Oligocarpia gutbieri, Göpp.}

Fig. Io. Photograph by transmitted light of a transfer preparation showing sterile $(a)$ and fertile $(b b)$ pinnules. $\times 3.2$. $\times 60$.

Fig. II. Photomicrograph of three sori. $a$, annulus; $v$, vein to sorus; $w$, main vein of pinnule.

\section{Psilophyton princeps, Dawson.}

Fig. 12. Photograph, partly by transmitted, partly by reflected light, of a transfer preparation. $a$, one of the spines on the surface of the preparation; $b$, spine exhibiting the basal expanded portion. $\times 3$.

Fungus (spore-form, cf. Dematiaceae).

Fig. I3. Photomicrograph of a transfer preparation showing mass of septate spores. $\quad \times 250$. 


\section{$2 \mathrm{BHL}$ Biodiversity Heritage Library}

Walton, John. 1923. "On a new method of investigating fossil plant impressions or incrustations." Annals of botany 37, 379-391. https://doi.org/10.1093/oxfordjournals.aob.a089855.

View This Item Online: https://www.biodiversitylibrary.org/item/270686

DOI: https://doi.org/10.1093/oxfordjournals.aob.a089855

Permalink: https://www.biodiversitylibrary.org/partpdf/319092

\section{Holding Institution}

New York Botanical Garden, LuEsther T. Mertz Library

\section{Sponsored by}

BHL-SIL-FEDLINK

\section{Copyright \& Reuse}

Copyright Status: Public domain. The BHL considers that this work is no longer under copyright protection.

This document was created from content at the Biodiversity Heritage Library, the world's largest open access digital library for biodiversity literature and archives. Visit BHL at https://www.biodiversitylibrary.org. 